\title{
Imprint smear- A valid intraoperative diagnostic tool in breast lesions
}

\author{
Authors \\ Dr Ronald J. Bosco, Dr Sarada V., Pramila R \\ Trichy SRM Medical College \\ Email: ronaldaswathy@gmail.com, Mobile: 9489214244
}

\section{Introduction}

Intraoperative cytology is a common technique used in the diagnosis of CNS neoplasms. Similarly, Imprint cytology technique in breast lesions is a simple and cost effective on table diagnostic tool where facilities for the commonly used frozen section studies are not available. ${ }^{1-6}$ Imprint is comparable to frozen section as a tool for intra operative and post-mortem diagnosis ${ }^{7-10}$ In this study we evaluate the accuracy of imprint cytology in rapid on table diagnosis of breast lesions in comparison with histopathology.

\section{Subjects and Methods}

The present study is a cross sectional study performed on all specimens of breast lesions received over a period of 17 months from September 2012 to January 2014. All breast specimens including mastectomy, lumpectomy, excision are included in the study with the exclusion of trucut biopsy. A total number of 71 cases were obtained.

Clinical and gross details of the patients were recorded. Imprint cytology of freshly excised tissue is prepared and stained with toluidene blue and Giemsa stains. The smears were studied and specific cytological diagnosis were made independently. The imprint smear findings are categorized into benign and malignant groups. Routine hematoxylin and eosin staining were done on tissue sections after fixation and histopathological diagnosis were made for the lesions. Taking histopathology as a gold standard, sensitivity, specificity, positive predictive value and negative predictive value for diagnosing malignant lesions by imprint cytology are calculated.

\section{Results}

In the present study, out of 71 cases obtained from mastectomy, lumpectomy and excision, 59 cases were benign and 12 cases were malignant cases. The benign lesions were found to be more common with a $83 \%$ of distribution. Distribution of lesions in the present study are summarised in the table 1. Among all the lesions, fibroadenoma was found to be the commonest lesions (56\%) followed by invasive ductal carcinoma (17\%). Fibrocystic disease was found as an individual disease in $10 \%$ cases and also in association with fibroadenoma in $17 \%$ of cases. Overall, breast lesions were common in the third and fourth decade of life $(58 \%)$. Relative number of benign and malignant lesions in different age groups are summarised in figure 1 . 
In Imprint smear, most of the malignant lesions showed high cellularity except one case ,which was subjected to mastectomy after lumpectomy. Fibroadenoma showed predominantly high to moderate cellularity, except for two cases, which showed small cohesive clusters of cells with presence of myoepithelial cells and based on that, those lesions were interpreted as benign proliferative lesion on imprint smear. Histopathology showed increased stromal cellularity in the above cases, reflected by the presence of fibroblasts in imprint smear. Sixty percent of the hypocellular lesions included gynacomastia and fibrocystic disease. Cases of fibrocystic disease with hypercellularity on imprint smear showed associated ductal hyperplasia in histopathological examination. One case of epidermal cyst showed only anucleated squamous cells on imprint cytology. Cellularity of various lesions in imprint smear is summarised in the table 2. Necrosis was identified by imprint smear in all malignant cases and two cases of granulomatous mastitis. Other secondary features appreciated in imprint smear evaluation of were cystic change, hyperplasia and apocrine metaplasia.

Presence of myoepithelial cells was found to be specific for diagnosis of benign lesions by imprint smear study. Significance of myoepithelial cells in the diagnosis of benign lesions are summarised in the table 3, table 4 . Six benign lesions were found to have no myoepithelial cells, including two cases of granulomatous mastitis dominated by inflammatory cells. Others include fibrocystic disease with scanty cellularity, gynacomastia with stroma predominant pattern, epidermal cyst and benign stroma predominant phylloides tumor which yielded hypercellular spindle cells in imprint smears.

Current study showed that in comparison with histopathology, imprint smear has $100 \%$ sensitivity and specificity in diagnosing a malignant lesion. The significance of imprint smear in the diagnosis of malignancy are summarised in the table 5, table 6 .

Table 1 Distribution of various lesions in the present study

\begin{tabular}{|l|c|}
\hline Lesions & No of cases \\
\hline Fibroadenoma & 28 \\
\hline Fibroadenoma with fibrocystic disease & 12 \\
\hline Fibrocystic disease & 7 \\
\hline Gynacomastia & 6 \\
\hline Benign phylloidestumor & 1 \\
\hline Intra ductal papilloma & 1 \\
\hline Epidermal cyst & 1 \\
\hline Granulomatous mastitis & 3 \\
\hline Ductal carcinoma & 12 \\
\hline Total & 71 \\
\hline
\end{tabular}

Table 2 Cellularity of various lesions in imprint smears

\begin{tabular}{|l|c|c|c|c|c|c|c|c|c|}
\hline Cellularity & FA & FCD & GYN & PAP & PHYL & GM & EC & CA & TOTAL \\
\hline High & 30 & 3 & 1 & 1 & 1 & 3 & 0 & 11 & 50 \\
\hline Moderate & 8 & 1 & 2 & 0 & 0 & 0 & 0 & 0 & 11 \\
\hline Low & 2 & 3 & 3 & 0 & 0 & 0 & 1 & 1 & 10 \\
\hline Total & 40 & 7 & 6 & 1 & 1 & 3 & 1 & 12 & 71 \\
\hline
\end{tabular}

Table 3 Presence of myoepithelial cells in imprint smears of benign and malignant lesions

\begin{tabular}{|l|c|c|}
\hline \multirow{2}{*}{} & \multicolumn{2}{|c|}{ Nature of lesion by histopathology } \\
\cline { 2 - 3 } & Benign & Malignant \\
\hline Myoepithelial cells present in imprint smear & 53 & 0 \\
\hline Myoepithelial cells absent in imprint smear & 6 & 12 \\
\hline
\end{tabular}


Table 4 Significance of myoepithelial cells in the diagnosis of benign lesions by imprint smear

\begin{tabular}{|l|c|c|c|c|}
\hline Presence of myoepithelial cells in & Sensitivity & Specificity & Positive predictive vale & Negative predictive vaue \\
\cline { 2 - 5 } a benign lesion by imprint smear & $89.83 \%$ & $100 \%$ & $100 \%$ & $66.67 \%$ \\
\hline
\end{tabular}

Table 5 Number of benign and malignant lesions by imprint smear and histopathology

\begin{tabular}{|l|c|c|}
\hline \multirow{2}{*}{} & \multicolumn{2}{|c|}{ Nature of lesion by histopathology } \\
\cline { 2 - 3 } & Benign & Malignant \\
\hline Benign lesion by imprint smear & 59 & 0 \\
\hline Malignant lesion by imprint smear & 0 & 12 \\
\hline
\end{tabular}

Table 6 Significance of imprint smear in the diagnosis of malignancy

\begin{tabular}{|l|c|c|c|c|}
\hline $\begin{array}{l}\text { Diagnosis of a malignant } \\
\text { lesion by imprint smear study }\end{array}$ & Sensitivity & Specificity & $\begin{array}{c}\text { Positive predictive } \\
\text { vale }\end{array}$ & $\begin{array}{c}\text { Negative predictive } \\
\text { vaue }\end{array}$ \\
\cline { 2 - 5 } & $100 \%$ & $100 \%$ & $100 \%$ & $100 \%$ \\
\hline
\end{tabular}

Table 7 Comparison of distribution of benign and malignant cases with previous

\begin{tabular}{|c|c|c|c|}
\hline Study & Sample size & Benign & Malignant \\
\hline Khanna et al $^{11}$ & 1315 & $61.3 \%$ & $38.7 \%$ \\
\hline Hassanian et al $^{4}$ & 110 & $73.6 \%$ & $26.4 \%$ \\
\hline Malik et al $^{12}$ & 1824 & $89 \%$ & $11 \%$ \\
\hline Present study & 71 & $83.09 \%$ & $16.91 \%$ \\
\hline
\end{tabular}

Table 8 Comparison of sensitivity, specificity, positive predictive value, negative predictive value and accuracy of imprint cytology in literature

\begin{tabular}{|c|c|c|c|c|c|}
\hline Study & Sensitivity & Specificity & $\begin{array}{c}\text { Positive } \\
\text { predictive value }\end{array}$ & $\begin{array}{c}\text { Negative } \\
\text { predictive value }\end{array}$ & Accuracy \\
\hline Ammar et al $^{1}$ & - & - & - & - & $94 \%$ \\
\hline${\text { Hiregouder et } \mathrm{al}^{2}}^{2}$ & - & - & - & - & $97.5 \%$ \\
\hline Hassanian et $\mathrm{al}^{4}$ & $96.3 \%$ & $100 \%$ & $100 \%$ & $98.6 \%$ & $98.9 \%$ \\
\hline Maria $\mathrm{F}$ et $\mathrm{al}^{5}$ & $100 \%$ & $100 \%$ & - & - & - \\
\hline 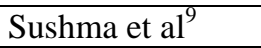 & - & - & - & - & $90 \%$ \\
\hline Khanna et al $^{11}$ & $98.4 \%$ & $100 \%$ & - & - & $98.8 \%$ \\
\hline Akhtar et al $^{21}$ & $100 \%$ & $100 \%$ & $100 \%$ & $100 \%$ & $100 \%$ \\
\hline Lee et $\mathrm{al}^{22}$ & - & - & - & - & $92.9 \%$ \\
\hline Dutta et $\mathrm{al}^{23}$ & - & - & - & - & $94 \%$ \\
\hline Scopa et $\mathrm{al}^{24}$ & $100 \%$ & $100 \%$ & - & - & $100 \%$ \\
\hline Present study & $100 \%$ & $100 \%$ & $100 \%$ & $100 \%$ & $100 \%$ \\
\hline
\end{tabular}

\section{Discussion}

Carcinoma of the breast is one of the leading cause of death almost exclusively in women, but can also occur in men. There is a requirement for rapid diagnostic tool for on table diagnosis to decide on the mode and extent of surgery. Presently frozen section is the widely used technique, which is expensive. In this context, review of literature and present study validates the role of imprint smear in this regard.

Comparison of distribution of benign and malignant cases with previous literature are summarised in the table 7. Observations in our study varied slightly due to variable sample size and duration of study. Peak age group for malignancy was 40-49 in present study, comparable with previous literature ${ }^{4,13}$ Malik et al reported ductal carcinoma as the most common malignant lesion which is compatible with the present study ${ }^{12}$.

Tissue surface to be imprinted should be flat, there should be no fat protruding from the edges, as these smudge the smear. First smears usually contain excess tissue fluid and blood, subsequent imprints usually give better cytological results. Quality of smears can be improved by blotting the cut surface of the specimen by an absorbent material to remove excess of fluid and blood. 
Benign lesions require more pressure during imprinting. ${ }^{9}$ These techniques were adopted in the present study.

According to literature, imprint smears with cytological features like uniform sized cells, normal nucleo-cytoplasmic $(\mathrm{N}$ : $\mathrm{C})$ ratio, fine chromatin are classified as 'negative for malignancy'. Smears with increased cellularity, large, hyperchromatic, pleomorphic nuclei, high $\mathrm{N}$ : C ratio and irregular coarse chromatin are features of malignancy. Exceptions can be observed where carcinoma with dense fibrous stroma yields less cellularity ${ }^{6}$. Fibroadenoma inspite of being benign, are usually highly cellular. ${ }^{9}$ Smears showing predominantly benign pattern with few atypical cells having high $\mathrm{N}$ : $\mathrm{C}$ ratio can be reported as' negative for malignancy with atypia'. Smears showing predominantly hemorrhage with occasional or no epithelial cells can be regarded as inadequate ${ }^{9,14-19}$. Haeri et al described a criteria for imprint cytology including cellularity, loss of cohesion, atypia, myoepithelial cells and nucleoli which were also followed in this study for evaluation ${ }^{20}$

In this study, smears from benign lesions are thin and uniform while malignant are thick and irregularly spread. Most of the smears were hypercellular with sheets, clusters or singly scattered pattern. More malignant the tumor, more cellular are the smears with more loss of cohesiveness. These findings were comparable with the literature.

Present study had $100 \%$ sensitivity, specificity, accuracy in diagnosing benign and malignant lesions, also taking into account the gross and clinical findings. All these results was comparable with the previous literature. Comparison of sensitivity, specificity, positive predictive value, negative predictive value and accuracy of imprint cytology in literature is summarised in the table 8 . Suen et al analysed 473 breast cases and found out that in all cases where gross and clinical findings suggested malignancy, imprint smear was able to diagnose lesions accurately ${ }^{25}$.
Errors in diagnosis of malignant tumors are due to paucity of cellular material, lack of clarity of cellular structures or indefinite malignant characteristics. Smears can be inadequate due to faulty technique, small size of the lesion and in cases of fibrotic lesions. Comedocarcinoma may yeild amorphous material because of the possibility of smear being taken from the necrotic area. Misdiagnosed lesions by imprint cytology are reported in literature which includes papillary lesions, lesions showing low-grade atypia, lesions showing low cellularity, lesions with ductal hyperplasia or ductal carcinoma in situ, lobular carcinoma, low-grade carcinomas (e.g., tubular carcinoma), small foci of carcinoma or a complex proliferative/atypical hyperplastic foci in fibrocystic diseases and radiotherapy induced changes. ${ }^{3,25-28}$ Literature shows that a positive diagnosis of malignancy is more reliable than negative diagnosis and they imply the importance of latter cases subjected to lumpectomy to rule out underlying malignancy. ${ }^{9,29}$ Imprint cytology should always be interpreted in the light of clinical and gross findings $s^{2,28,30}$. Negative diagnosis should be disregarded if gross appearance of lesion suggests malignancy. ${ }^{25}$ This technique doesn't provide information on the depth of infiltration of tumor although it might provide information on the original site of tumor. ${ }^{30}$ Imprint cytology has the advantage of providing better cellular morphology and fewer artifacts. On the other hand Frozen Sections provides more tissue architectural details but frequently hampered by freezing artefact. ${ }^{2,10,20,29}$ Cases like Fibroadenomas can present a very worrying appearance particularly in pregnancy, lactation or when they occur in an elderly woman. Necrotic debris can be seen in inflammatory conditions. Inflammatory conditions can be associated with marked reactive atypia of epithelial cells. $^{29}$

\section{Acknowledgement}

I would like to thank my colleagues, clinicians and lab technicians for their support they gave th carryout this study successfully. 


\section{References}

1. Ammar CA et al. Intra- operative cytology and frozen sections of breast lesions: a comparison from a Saudi teaching hospital. Bahrain Medical Bulletin 1996; 18:1.

2. Hiregoudar AD, Godhi AS, Malur PR, Gogeri BV, Metgud SC. Accuracy of intraoperative imprint smears in breast tumours: A study of 40 cases with review of literature. Indian Journal of Surgery 2006;68:302-305.

3. Kazuhiro $\mathrm{S}$ et al. Usefulness of intraoperative touch smear cytology in breast- conserving surgery. Experimental and therapeutic medicine 2010; 1:641-45.

4. Hassanain HK et al. Role of imprint cytology in breast lesions. Iraqi J Med Sci 2009; 7(4):61-66.

5. Maria $F$ et al. Imprint cytology on microcalcifications excised by Vacuumassisted breast biopsy: a rapid preliminary diagnosis. World Journal of Surgical Oncology 2007, 5:40.

6. Kashiwagi $S$ et al. Adjunctive imprint cytology of core needle biopsy specimens improved diagnostic accuracy for breast cancer. SpringerPlus 2013; 2:372.

7. Sahil IP et al. Utility of fine needle aspiration cytology in the evaluation of breast lesions. Journal of Clinical and Diagnostic Research. 2013; 7(12): 2777-2779.

8. Sachin SK et al. Role of scrap cytology in the intraoperative diagnosis of tumor. J Cytol 2010; 27(3):86-90.

9. Sushma NR et al. Imprint smear cytology and histopathology of breast lesions - a comparative evaluation with review of literature. Cibtech Journal of Bio-Protocols 2012; 1 (2):22-27.

10. Akbar $\mathrm{S}$ et al. Comparing touch imprint cytology, frozen section analysis, and cytokeratin immunostaining for intraoperative evaluation of axillary sentinel lymphnodes in breast cancer. Indian J Pathol Microbiol 2012; 55(2).
11. Khanna R, Khanna S, Chaturvedi $S$ and Aryya NC. Spectrum of breast disease in young females - A retrospective study of 1315 patients. Indian J Pathl Microbiol 1988;41(4):379-401.

12. Malik R, Bharadwaj VK. Breast lesions in young females-- a 20-year study for significance of early recognition. Indian $\mathrm{J}$ PatholMicrobiol 2003;46(4):559-562.

13. El Saghir et al. Age distribution of breast cancer in Lebanon: increased percentages and age adjusted incidence rates of youngeraged groups at presentation. J Med Liban.2002;50(1-2):3-9.

14. Stanley MW et al. Current issues in breast cytopathology. Am J Clin Pathol 2000;113 (1):S49-S75.

15. Shah $\mathrm{SH}$ et al. Diagnostic evaluation of fine needle aspiration cytology in the management of palpable breast lesions. JPMA 1998;48:7.

16. Nandhini NM et al. Evaluation of scoring system in cytological diagnosis and management of breast lesion with review of literature. Indian Journal of Cancer 2011; 48(2).

17. Dudgeon LS, Barrett NR. The examination of fresh tissues by the wet film method. British Journal of Surgery 1934; 22:4-22.

18. Prakash HM et al. The value of systemic pattern analysis in FNAC of breast lesions: 225 cases with cytohistological correlation. J Cytol 2011; 28(1):13-19.

19. Tribe CR. Cytological diagnosis of breast tumors by the imprint method. Journal of Clinical Pathology 1965;18:31-39.

20. Haeri $\mathrm{H}$ et al. Comparision of the cytology technique and the frozen section results in intraoperative consultation of the breast lesions. Acta Medica Iranica 2002; 40(3):203-206.

21. Akthar ZM et al. Evaluation of accuracy of intra operative imprint cytology for detection of breast lesions. Annals 2010; 16(1). 
22. Lee TK. The value of imprint cytology in tumor diagnosis. A retrospective study of 522 cases in northern China. ActaCytologica 1982;26:169-171.

23. Dutta SK, Chattopadhyaya A, Roy S. Evaluation of fine needle aspiration and imprint cytology in early diagnosis of breast lesions with histopathological correlation. Journal of Indian medical Association 2001;99(8):421-3.

24. Scopa CD et al. Tissue imprints in surgical pathology: a rapid intraoperative diagnostic aid. DiagnCytopathol 1990; 6(1) :5-8.

25. Suen KC, Woods WS, Syed AA, Quenville NF, Clement PB. Role of imprint cytology in intra operative diagnosis: value and limitations. Journal of Clinical Pathology 1978;31:328-337.

26. Mortensen E, Hansen L. Imprint as a reliable diagnostic tool in breast cancer and possible usefulness for research purposes. Breast cancer research 2005; 7(2):3.

27. Anastasiadis P, Romanidis K. Proliferative breast disease: epidemiological aspects and cytological diagnosis. European J Gynaecol Oncol 2003; 24(6):547-51.

28. Gray W, McKee GT. Diagnostic cytopathology $8^{\text {th }}$ ed. 2004;p 648-9.

29. Tarek MN et al. Intra-Operative Diagnosis of Breast Mass-Lesions: Comparison of the validity of touch smear preparation and frozen section techniques. Journal of the Egyptian Nat. Cancer Inst. 2008; 20(1):6369.

30. Rakesh M, Ashok P et al. Study of imprint smears of various lesions with histological correlation. International journal of medical science and public health 2014; 3(4). 